DOI: https://doi.org/10.31073/abg.60.18

\title{
IMPROVEMENT OF BROWN CARPATHIAN CATTLE BREED BY THE METHOD OF "SINGLE CROSSING" OF LEBEDYN BREED
}

\author{
A. YE. POCHUKALIN, S. V. PRYIMA, O. V. RIZUN \\ Institute of Animal Breeding and Genetics nd. a. M.V.Zubets of NAAS (Chubynske, Ukraine) \\ https://orcid.org/0000-0003-2280-5371 - A. Ye. Pochukalin \\ https://orcid.org/0000-0001-9902-4325 - S. V. Pryima \\ https://orcid.org/0000-0001-8205-3656-O. V. Rizun \\ Pochuk.A@ukr.net
}

The Lebedyn breed of the combined direction of productivity was used for improvement of economically useful signs, especially milk productivity of cows of Brown Carpathian breed. Both breeds belong to the dual-purpose direction of productivity, they are adapted to the natural and climatic zones of breeding and "belong" to a related group of brown breeds.

The largest related group of the Brown Carpathian breed are the descendants of the bull Rupora 6507, to which the "single crossing" of the Lebedyn breed of the dual-purpose direction of productivity was carried out. In addition, the following servicing bulls of the Lebedyn breed were used to improve the economically useful characteristics of the Brown Carpathian breed: Tuman 779 Shafran 2012, Henii 958, Kokos 923 (related group of Elbrus 1871) Zhdanyi 035, Limonad 2188, (line of Narzan 937) Landysh 2012 (related group of Rolik 113) Minus 1353 (line of FordzonMylyi 290). The Lebedyn breed has played an important role in strengthening the productive characteristics of Brown Carpathian breed and expanding its genealogical structure.

Keywords: Brown Carpathian breed, Lebedyn breed, bull-sires, related group, line, single crossing

\section{УДОСКОНАЛЕННЯ БУРОЇ КАРПАТСЬКОЇ ПОРОДИ ВЕЛИКОЇ РОГАТОЇ ХУДОБИ МЕТОДОМ “ПРИЛИТТЯ КРОВІ" ЛЕБЕДИНСЬКОЇ ПОРОДИ}

А. С. Почукалін, С. В. Прийма, О. В. Різун

Інститут розведення і генетики тварин імені М.В.Зубия НААН (Чубинське, Украӥна)

Для удосконалення господарськи корисних ознак, особливо молочної продуктивності корів бурої карпатської породи великої рогатої худоби, використовувалась лебединська порода комбінованого напряму. Обидві породи належать до молочно-м'ясного напряму продуктивності, пристосовані до природо-кліматичних зон розведення $і$ “входять”" до спорідненої групи бурих порід.

Найбільшою спорідненою групою бурої карпатської породи, до якої "прилили кров" лебединської породи комбінованого напряму продуктивності є потомки бугая Рупора 6507. Поза тим, для удосконалення господарськи корисних ознак бурої карпатської породи великої рогатої худоби використовувались наступні бугаї-плідники лебединської породи: Туман 779, Шафран 2012, Геній 958, Кокос 923 (споріднена група Ельбруса 1871); Жданий 035, Лімонад 2188 (лінія Нарзана 937); Ландиш 2012 (споріднена група Роліка 113); Мінус 1353 (Лінія Фордзона-Милого 290). Крім підсилення продуктивних ознак бурої карпатської худоби, лебединська порода відіграла важливу роль у розширенні ї̈ генеалогічної структури.

Ключові слова: бура карпатська порода, лебединська порода, бугай-плідник, споріднена група, лінія, прилиття крові

\section{СОВЕРШЕНСТВОВАНИЕ БУРОЙ КАРПАТСКОЙ ПОРОДЫ КРУПНОГО РОГАТОГО СКОТА МЕТОДОМ "ПРИЛИТИЯ КРОВИ" ЛЕБЕДИНСКОЙ ПОРОДЫ}

Розведення і генетика тварин. 2020. Вип. 60 
А. Е. Почукалин, С. В. Прыйма, О. В. Ризун

Институт разведения и генетики животных имени М.В.Зубиа НААН (Чубинское, Украина)

Для усовершенствования хозяйственно полезных признаков, особенно молочной продуктивности коров бурой карпатской породы крупного рогатого скота, использовалась лебединская порода комбинированного направления. Обе породы относятся к молочно-мясному направлению продуктивности, приспособленные к природно-климатическим зонам разведения и “входят” в родственную группу бурых пород.

Наибольшей родственной группой бурой карпатской породы, к которой "прилили кровь" лебединской породы комбинированного направления производительности являются потомки быка Рупора 6507. Помимо того, для совершенствования хозяйственно полезных признаков бурой карпатской породы крупного рогатого скота использовались следующие быки-производители лебединской породы: Туман 779, Шафран 2012 Гений 958, Кокос 923 (родственная группа Эльбруса 1871); Жданый 035, Лимонад 2188 (линия Нарзана 937) Ландыши 2012 (родственная группа Ролика 113) Минус 1353 (Линия Фордзона-Милого 290). Кроме усиления продуктивных признаков бурого карпатского скота, лебединская порода сыграла важную роль в расширении ее генеалогической структуры.

Ключевые слова: бурая карпатская порода, лебединская порода, бык-производитель, родственная группа, линия, прилитие крови

Introduction. According to MA Kravchenko, "Single crossing is only a small temporary deviation from pure breeding in order to borrow from another breed some qualities that are absent from this breed, provided that the type and characteristics of this breed are preserved" [1].

Along with pure breeding in dairy cattle breeding is widely used "single crossing" or "simple crossing". In addition, among the main tasks of the use of "single crossing" is the creation of new local lines and types in the breed, as well as the expansion of combinatorial variability in the breed for efficient selection $[2,3]$.

In domestic practice, the method of "single crossing" was used to improve the productive qualities of Ukrainian Whiteheaded with Estonian Black-and-White, Red Steppe with Angler, Lebedyn with Jersey and Brown Carpathian breed with Lebedyn [4-7].

The Lebedyn breed of the combined direction of productivity was used for improvement of economically useful signs, especially milk productivity of cows of Brown Carpathian breed. Both breeds belong to the dual-purpose direction of productivity, they are adapted to the natural and climatic zones of breeding and "belong" to a related group of brown breeds [8-10].

The aim of the study is to characterize purebred bulls of Lebedyn breed, as well as not a purebred with Brown Carpathian breed by origin, live weight and exterior. The aim was also to analyze the evaluation of bulls by posterity by the method of "daughters-peers", and to determine the genealogical affiliation to related groups.

Materials and methods of research. The material for the research was the State books of breeding animals of Brown Carpathian breed of cattle of eight volumes: 1948, 1968, 1972, 1975, 1978, 1983, 1987, 1992. For the characteristic servicing bulls were used information on the origin, live weight, measurements of bulls, milk productivity of mothers cows and belonging to lines and related groups. Catalogs of servicing bulls of dairy breeds, evaluated by the quality of the posterity for 1985, 1987-1990 were used for the results of evaluation of bulls of lines and groups. Reduction of breeds in the article is indicated - BC (Brown Carpathian breed), BS (Brown Swiss), LE (Lebedyn), J (Jersey).

The results of research. The largest related group of the Brown Carpathian breed are the descendants of the bull Rupor 6507, to which the "single crossing" of the Lebedyn breed of the dualpurpose direction of productivity was carried out. Rupor 6507 is not a purebred bull - 3/4LE1/4J with a score of B2. Origin of a bull: mother - cow Dumka 1904 HLM-44 from which for VI lactation was received $4677 \mathrm{~kg}$ with a fat content of 5.11\%; father - bull Radist 584 SUL-1126. The branch of the related group Rupor 6507 passed through two bulls of Radius 745 and Record 737 (picture 1). 
The bull Radius 745 (1/2BC3/8LE1/8J) was born in 1972 in a breeding farm at the Zakarpattia Regional Agricultural Research Station of the Berehiv District of the Zakarpattia Region. It was born from a highly productive cow of the Suvora 3747 ZKZ-1699 (3-302-7591-4.13-314) line Fitzko 33. It color was brown, weight $760 \mathrm{~kg}$ at the age of 2 years 11 months at a height at the withers of $140 \mathrm{~cm}$, chest depth $212 \mathrm{~cm}$ and a pastern girth of $24 \mathrm{~cm}$. From 20 daughters for the first lactation $2876 \mathrm{~kg}$ of milk with a fat content of $3.73 \%$ and $107 \mathrm{~kg}$ of milk fat were obtained. Estimation for the difference of DP $+865 \mathrm{~kg}$ for milk yield, $+0.06 \%$ for fat content and $+34 \mathrm{~kg}$ for the amount of milk fat. From Radius 745, 24 descendants (18 sons and 6 grandchildren) are recorded in the State books, of which six sons were evaluated by the method of "daughter-peer". The bulls Ranok 8597 with genotype 3/4BC1/16J3/16LE (DS: $-61 \mathrm{~kg}, \quad-0.02 \%,-3 \mathrm{~kg}$ ) and Reserv 9007 with genotype $1 / 2 \mathrm{BC} 1 / 4 \mathrm{BS} 1 / 16 \mathrm{~J} 3 / 16 \mathrm{LE}$ (DS: $-160 \mathrm{~kg},-0.03 \%,-6 \mathrm{~kg}$ ). We should pay attention to the following bulls, which had a positive trend in the evaluation of the comparison of "daughter-peers":

- Radyi 3817 - 16D-1-2566-3.67-94; DP: +52, +0,01, +14;

- Romb 8829 (1/2BC1/4BS1/16J3/16LE) - 15D-1-2902-3.50-102; DP: +185, -0.02, +6;

- Rebus 8595 (5/8BC1/8BS1/16J3/16LE) - 16D-1-2771-3.54-98; DP: +198, +0.02, +8.

Padist $584 \longrightarrow$ Rupor 6507

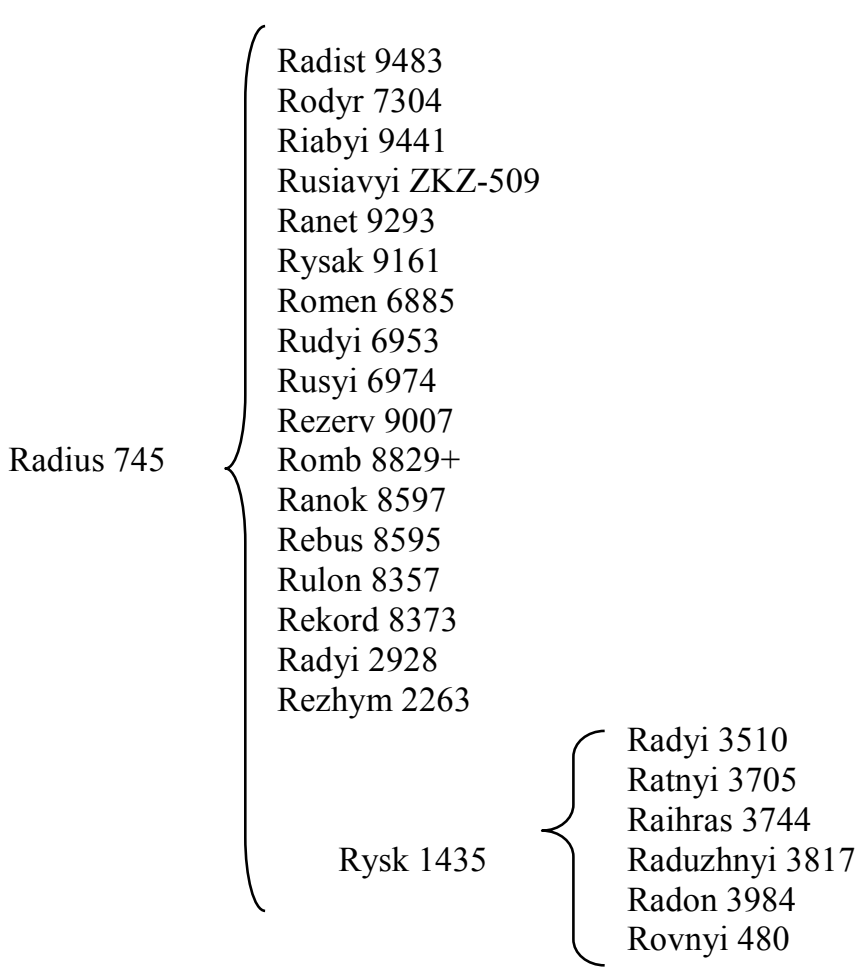

Rekord 737

$\left\{\begin{array}{l}\text { Radius } 1999 \\ \text { Rulet } 2563\end{array}\right.$

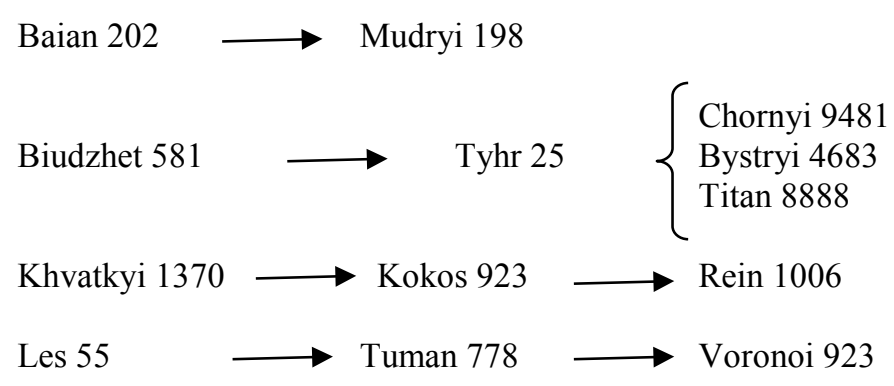

Picture 1. Schemes of using bulls of Lebedyn breed in the genealogical structure of Brown Carpathian breed

The place of the evaluation was the farms "Vynohradar" Irshavsky, "Progress", "Kommunar" 
Vynohradiv districts of Zakarpattia region. A total of 194.7 thousand doses of semen were accumulated from the five sons of Radius 745.

Thus, in our opinion, the son of Radius 745 bull Risk 1435 with genotype 3/4BC3/16LE1/ 16J deserves attention, who was born in 1975 on the farm. Lenin, Mukachevo district, Zakarpattia region. Cow Chasha 4200 ZKZ-2206 is the mother of a bull Risk 1435, from which $6139 \mathrm{~kg}$ of milk with a fat content of $3.90 \%$ was obtained during the second lactation. Risk 1435 at 18 months weighed $417 \mathrm{~kg}$, height at withers $137 \mathrm{~cm}$. It was received the quality of the posterity - 17D-I L.-2795-3.71104 , with a difference of DP: $+259 \mathrm{~kg},+0.02 \%,+10 \mathrm{~kg}$. Six of his sons were recorded in the State books of breeding animals, three of which were rated by the quality of the posterity:

- Raduzhnyi 3817 (5/8BC1/4BS3/32LE1/32J) - 15D-1-3221-3.62-116; DP: +385, +0.01, +14 . The place of evaluation is "XXII Party Congress" Mukachevo district of Zakarpattia region, produced 17.7 thousand doses of sperm.

- Radyi 3510 - 15D-1-2616-3.73-98; DP: -160, +0,08, -4.

- Radon 3510 (7/8BC3/32LE1/32J) - 15D-1-2737-3.62-99; DP: -29, +0.02, -1. The place of evaluation is the Way to Communism in the Berehiv district of the Zakarpattia region, 40.4 thousand doses of semen were produced, of which 600 doses were used.

In addition, to improve the economically useful characteristics of the Brown Carpathian breed of cattle were used the following servicing bulls of Lebedyn breed:

RELATED GROUP OF ELBRUS 1871 SUL-160. TUMAN 779, SHAFRAN 2012, HENII 958, were born in 1955-1956 in the breeding farm "Mykhailivka" of Sumy region. They are the descendants of the bull Les 55 SUL-185 (5 years - $1070 \mathrm{~kg}$ ). The stirps of the group is found in the third line of ancestors. Live weight and milk productivity of mothers is respectively: 4 years 9 months. $-990 \mathrm{~kg}, 3$ years 10 months. $-900 \mathrm{~kg}, 3 \mathrm{p}-804 \mathrm{~kg}$; 3-264-4851-3.9 (Tundra 285 SUL890), 3-300-5787-3.8 (Shala 259 SUL-888), 4-300-6480-3.9 (Gorda 48 SUL-875).

KOKOS 923, it belonged to the Chupakhiv beet factory of the Okhtyrka district of the Sumy region. Live weight $1059 \mathrm{~kg}$ at the age of 4 years 8 months. The mother of the bull Kokos 923 was the cow Kanareika 03 SUL-621, which during the second lactation gave $5845 \mathrm{~kg}$ of milk with a fat content of $3.85 \%$. The parent side is also saturated with highly productive animals: Khvoia 1370 SUL-629 (MB) - 6-300-6025-4.02; Khrystia 116 DPK-182 - 2-300-5223-3.86.

The bulls of the related group Elbrus 1871 belonged to the Station of Artificial Insemination of Agricultural Animals of the Zakarpattia Regional Agricultural Research Station and the Mukachevo Regional State Station of Breeding and Artificial Insemination of Farm Animals.

LINE NARZANA 937 SHB-126. ZHDANY 035 was born in 1955 in the Sumy region. At 4 years and 5 months, he weighed $1000 \mathrm{~kg}$ with 85 points for the exterior. He comes from the bull Aron 068 SUL-139 (6 years 9 months $997 \mathrm{~kg}$ ), whose father is the stirps of the line in the Lebedyn breed.

LIMONAD 2188 comes from the bull Almaz 54 SUL-339 (2 years 4 months $-710 \mathrm{~kg}$ ). Narzan 937 is a great-grandfather and is in the third line of ancestors. Its live weight at 2 years 10 months is $600 \mathrm{~kg}$. It belonged to the Station of Artificial Insemination of Agricultural Animals of the Mountain-Carpathian Agricultural Research Station.

RELATED GROUP ROLIK 113 SUL-11. LANDISH 2012 weighed $650 \mathrm{~kg}$. at 2 years 9 months. It comes from the cow Lyubka 342 (5-300-4310-3.85) and the bull Lux 471 SUL-258 (3 years $850 \mathrm{~kg}$ ). Rolik 113 is placed in the third row of ancestors.

LINE OF FORDZONA-MYLOHO 290. MINUS 1353 was born in 1957 in Sumy region. Its live weight at 2 years 10 months is $790 \mathrm{~kg}$. From his mother Mirna 911 for the first lactation was obtained $3215 \mathrm{~kg}$ of milk with a fat content of 3.82\%. His father's bull is Mylyi 290 successors to Fordzon. Minus 1353 belonged to the Uzhhorod State Station for Artificial Insemination of Agricultural Animals.

Conclusions. A Both breeds belong to a related group of brown breeds. Since the method in breeding work is short-lived, purebred bulls of known lines and related groups of Elbrus 1871, Narzan 937, Rolik 113 and Fordsona-Miloho 290 were used, as well as local bulls recorded in the State 
herd books. The Lebedyn breed has played an important role in strengthening the productive characteristics of Brown Carpathian breed and expanding its genealogical structure (related group of Rupor 6507).

\section{BIBLIOGRAPHY}

1. Кравченко Н. А. Разведение сельскохозяйственных животных. Москва : Колос, 1973. $418 \mathrm{c}$.

2. Полковникова О. П. Ввідне схрещування як метод створення нових ліній у породі. Молочно-м'ясне скотарство. 1976. Вип. 41. С. 28-30.

3. Борзов В. В. Перспективи створення внутріпородного типу симентальської худоби ввідним схрещуванням з айширською, монбельярдською і червоно-рябою голштино-фризькою породами на Україні. Молочно-м'ясне скотарство. 1981. Вип. 55. С. 3-9.

4. Бірюкова К. С. Ввідне схрещування як метод удосконалення порід. Молочно-м'ясне скотарство. 1979. Вип. 49. С. 14-22.

5. Борьба В. І., Дехтярьов П. А. Особливості ввідного схрещування червоної степової і англерської породи худоби. Молочно-м'ясне скотарство. 1982. Вип. 59. С. 15-20.

6. Заброварний О. М. Результати ввідного схрещування бурої карпатської худоби з лебединською породою. Молочно-м'ясне скотарство. 1970. Вип. 20. С. 11-15.

7. Байда В. І. Племінна робота із стадом лебединської породи в племзаводі “Українка”. Молочно-м'ясне скотарство. 1981. Вип. 56. С. 31-37.

8. Сірацький Й. 3., Меркушин В. В. Лебединська порода. Племінні ресурси України. Київ : Аграр. наука, 1998. С. 28-30.

9. Почукалін А. Є., Прийма С. В., Різун О. В. Селекційне надбання молочно-м'ясного скотарства України - бура карпатська порода. Розведення і генетика тварин. Київ, 2019. Вип. 58. C. 137-159 DOI: https://doi.org/10.31073/abg.58.18

10. Почукалін А. Є., Прийма С. В., Різун О. В. Стан племінного скотарства України за спорідненими групами молочних порід. Вісник Сумського національного аграрного університету. Серія : Тваринництво. 2017. № 7 (33). С. 92-96.

\section{REFERENCES}

1. Kravchenko, N. A. 1973. Razvedenie sel'skohozyajstvennyh zhivotnyh - Breeding of farm animals. Moskva, Kolos, 418 (in Russian).

2. Polkovnykova, O. P. 1976. Vvidne skhreshchuvannia yak metod stvorennia novykh linii u porodi - Single crossing as a method of creating new lines in the breed. Molochno-miasne skotarstvo - Dairy and meat cattle breeding. 41:28-30 (in Ukrainian).

3. Borzov, V. V. 1981. Perspektyvy stvorennia vnutriporodnoho typu symentalskoi khudoby vvidnym skhreshchuvanniam $\mathrm{z}$ aishyrskoiu, monbeliardskoiu i chervono-riaboiu holshtyno-fryzkoiu porodamy na Ukraini - Prospects for the creation of an intrabreed type of Simmental cattle by single crossing with Ayrshire, Montbeliarde and red-and-white Holstein-Friesian breeds in Ukraine. Molochno-miasne skotarstvo - Dairy and meat cattle breeding. 55:3-9 (in Ukrainian).

4. Biriukova, K. S. 1979. Vvidne skhreshchuvannia yak metod udoskonalennia pored - Single crossing as a method of breed improvement. Molochno-miasne skotarstvo - Dairy and meat cattle breeding. 49:14-22 (in Ukrainian).

5. Borba, V. I., and P. A. Dekhtiarov. 1982. Osoblyvosti vvidnoho skhreshchuvannia chervonoi stepovoi i anhlerskoi porody khudoby - Features of single crossing of Red Steppe and Angler breed of cattle. Molochno-miasne skotarstvo - Dairy and meat cattle breeding. 59:15-20 (in Ukrainian).

6. Zabrovarnyi, O. M. 1970. Rezultaty vvidnoho skhreshchuvannia buroi karpatskoi khudoby z lebedynskoiu porodoiu - Results of single crossing of Brown Carpathian cattle with Lebedyn breed. Molochno-miasne skotarstvo - Dairy and meat cattle breeding. 20:11-15 (in Ukrainian).

7. Baida, V. I. 1981. Pleminna robota iz stadom lebedynskoi porody v plemzavodi "Ukrainka" Breeding work with a herd of Lebedyn breed in the breeding farm "Ukrainka". Molochno-miasne skotarstvo - Dairy and meat cattle breeding. 56:31-37 (in Ukrainian). 
8. Siratskyi, Y. Z., and V. V. Merkushyn. 1998. Lebedynska poroda. Pleminni resursy UkrainyLebedyn breed. Breeding resources of Ukraine. Kyiv, Ahrarna nauka, 28-30 (in Ukrainian).

9. Pochukalin, A. Ye., S. V. Pryima, and O. V. Rizun. 2019. Selektsiyne nadbannya molochnom"yasnoho skotarstva Ukrayiny - bura karpat's'ka poroda - Breeding heritage of dairy-meat cattle of Ukraine - Brown Carpathian cattle. Rozvedennya i henetyka tvaryn - Animal Breeding and Genetics. Kyyiv, 58:137-159 DOI: https://doi.org/10.31073/abg.58.018. (in Ukrainian).

10. Pochukalin, A. Ye., S. V. Pryima, and O. V. Rizun. 2017. Stan pleminnoho skotarstva Ukrainy za sporidnenymy hrupamy molochnykh pored - The state of breeding cattle breeding in Ukraine by related groups of dairy breeds. Visnyk Sumskoho natsionalnoho ahrarnoho universytetu. Seriia: Tvarynnytstvo - Bulletin of Sumy national agrarian university. Livestock series. 7(33):92-96 (in Ukrainian).

Одержано редколегією 28.08.2020 p.

Прийнято до друку 07.10.2020 p. 